\title{
Döviz Kuru ile BİST Turizm Endeksi Arasındaki İlişkinin Analizi
}

\author{
DOI: 10.26466/opus.585398 \\ *
}

\section{Emine Soyaslan*}

* Yüksek Lisans Öğrencisi, Osmaniye Korkut Ata Üniversitesi, Iktisadi Ve Idari Bilimler Fakültesi, Osmaniye/Türkiye

E-Posta: emine.soyaslan828@gmail.com

ORCID: 0000-0003-0422-8574

\section{$\ddot{O} z$}

Bu çalışmada, BİST Turizm endeksi ile döviz kurları arasında kısa ve uzun dönemde bir ilişki olup olmadı̆̆ $r$ ekonometrik analiz yöntemiyle incelenmiştir. Bu amaçla 02/01/2015 ile 30/03/2018 tarihleri arası BİST Turizm endeksi ile Amerikan doları ve Euro para birimine ilişkin günlük verileri kullamılmıştır. Çalı̧̧mada yapılan analizler sonucunda elde edilen bulgulara gore uzun dönemde BİST Turizm endeksi ile döviz kurları arasinda bir eşbütünleşme ilişkisi olmadığı yani değişkenler uzun dönemde birlikte hareket etmediği gözlemlenmiştir. Uzun dönemde bir ilişki bulunmamasının yanında kısa dönemde Euro kurunda oluşan bir değişim \%5 anlamlllik seviyesinde BISST Turizm endeksi üzerinde etkili olduğu tespit edilmiştir. Bununla birlikte Amerikan dolarında oluşan bir değişim \%5 anlamlılık seviyesinde BISTT Turizm endeksi üzerinde etkili olmadığı bulunmuş ancak \%10 anlamlllik seviyesinde değerlendirildiğinde Amerikan dolarındaki bir değişme kısa dönemde BİST Turizm endeksi üzerinde etkili olduğu sonucuna varılmıştır. Çalı̧̧ma sonucunun getirdiği diğer bir sonuç, BİST Turizm endeksinde oluşan değişimlerin on dönemlik Varyans ayrıştırması testi neticesinde \%15.22 seviyesinde Euro kurundan, \%9.44 seviyesinde ise Amerikan dolarından kaynaklandığ sonucuna varılmıştır.

Anahtar Kelimeler: $\quad$ Döviz Kuru, BIST Turizm Endeksi, Johansen Eş Bütünleşme Testi, Varyans Ayrıştırması Testi 


\title{
Analysis of The Relationship Between Exchange Rate and Bist Tuorism Index
}

\begin{abstract}
In this study, a short- and long-term relationship between BIST Tourism Index and exchange rates was investigated by using econometric analysis method. For this purpose, BIST Tourism Index and US Dollar and Euro currency daily data are used between 02/01/2015 and 30/03/2018. in the study. According to the findings of the study, it was observed that there was no cointegration relationship between BIST Tourism Index and exchange rates in the long term, so the variables did not act together in the long term. In addition to the lack of any relationship in the long term, a change in the Euro exchange rate in the short term was found to be effective on the BIST Tourism Index at 5\% significance level. However, a change in the US dollar was not effective on the BIST Tourism index at 5\% significance level, but a change in the US dollar was found to be effective on the BIST Tourism Index in the short term when evaluated at 10\% significance level. As a result of the study, it was concluded that the changes in the BIST Tourism index stemmed from the Euro exchange rate at $15.22 \%$ and the US dollar at $9.44 \%$ as a result of the ten-year variance decomposition test.
\end{abstract}

Keywords: Exchange Rate, BIST Tourism Index, Johansen Cointegration Test, Variance Decomposition Test 


\section{Giriş}

Geçmişten günümüze gerek bilim ve teknolojide kat edilen gelişmeler gerek ticaret alanında küreselleşen alım ve satımlar ve aynı zamanda, gelişen dünya devletleri arasındaki iyi ilişkiler beraberinde ülke vatandaşlarının birçok ülkeye seyahat etmelerine, yabancı yatırımlar yapmalarına neden olmuştur.

Bununla birlikte özellikle finansal serbestleşme sürecinin ve uluslararası sermaye hareketlerinin ulaştığı boyut hisse senedi ile döviz piyasası arasındaki ilişkinin önemini daha da artırır hale getirmiştir (Büberkökü, 2013, s.2).

Özellikle bir ülkenin kendi para biriminin dönemler içerisinde istikrarsız bir seyir izlemesi sonucu, ilgili o ülkenin ekonomisini olumsuz yönde etkilemektedir. Bununla birlikte o ülke para birimiyle işlem yapan diğer ülkelerin ekonomik faaliyetilerinin olumsuz seyir izlemesine dolayısıyla en genel anlamda eknomik istikrarsızlığa yol açmaktadır. Firmalar için önemli bir unsur olan döviz yönetimi yabancı para cinsinden borç ve varlıkların en etkin ve karlı bir biçimde dengelenmesi olarak tanımlanan bir unsurdur. Döviz kurunun değişmesi firmaların yapısını etkilediği gibi makro ekonomileri de etkilemektedir. Özellikle uluslararası boyutta hizmet ve ürün ticareti yapan işletmelerin borç veya alacaklarından dolayı ülke para biriminin yabancı para birimleri veya yabanca para biriminin ülke para biriminin karşında değer kaybına uğraması sonucunda zarar tehlikesi yada kar ihtimali ortaya çımaktadır (Boyacıoğlu ve Çürük, 2016, s.144). Dolayısıyla bu firmalardan turizm sektöründe yer alan işletmelerde payını almaktadır.

Döviz kurlarındaki fiyat dalgalanmaları ile hisse senedi fiyatları arasındaki ilişkiyi açıklayan literatürde iki tür yaklaşımdan bahsedilmektedir. Bunlar geleneksel ve portföy yaklaşımıdır. Bunlardan ilk olarak geleneksel yaklaşıma gore, hisse senedi fiyatları ile döviz kurları arasında pozitif ve döviz kurlarından hisse senetlerine doğru bir nedensellik ilişkisi bulunmaktadır. Diğer bir yaklaşım olan portföy modeline göre ise, döviz kurları ile hisse senedi fiyatları arasında negatif bir ilişkiyi sahip olduğu ve nedenselliğin yönü ise hisse senedi fiyatından döviz kuruna doğru olduğunu belirtilmiştir (Erbaykal ve Okuyan, 2007, s.78). 
$\mathrm{Bu}$ çalışmanın amacı da borsa endekslerinde yer alan BİST Turizm endeksinin döviz kuruna olan duyarlılığının uzun ve kısa dönemde bir nedensellik ilişkisi var olup olmadığ 1 incelenecektir. Çalışmanın bundan sonraki bölümünde ele alınan konuyla ilgili literatürde yapılmış çalışmalara yer verilmiştir. Üçüncü bölümde çalışma için kullanılan yöntemleri belirtilmiştir. Sonraki aşamada araştırmanın amacı, veri seti ve örneklem açıklanarak araştırmanın bulguları kısmına geçilmiştir. Dördüncü bölüm olan bulgular kısmında, serilerin ilk düzeyde durağan olup olmadıklarına bakılıp değişkenlerin kısa dönemli ilişkilerine Granger nedensellik testi, uzun dönemli ilişkilerine Johansen eşbütünleşme yöntemi yardımıyla test edilmiştir. Değişkenlerin herhangi bir ekonomik olay karşısında nasıl bir tepki gösterdiğini öğrenmek için VAR Etki-Tepki fonksiyonu uygulanmıştır ve son olarak diğer bir zaman serisi yöntem olan varyans ayrıştırması yöntemi ile sınanmıştır. Daha sonra bulgular analiz edilerek sonuç kısmı oluşturulmuştur.

\section{Literatür Taraması}

Borsa İstanbul'da bulunan birçok endeks için, döviz kuruna olan duyarlılığ1 konusunda literatür de pek çok araştırma yapılmıştır. Bunlar arasında borsa endekslerinin sadece Amerikan dolarına olan duyarlılığı, Amerikan doları ile Euro döviz kurlarını birlikte ele alınarak üzerinde çalışma yapılmış, bunun yanında enflasyon, faiz oranı, altın fiyatları gibi birçok değişkeni içinde barındıran çalışmalara da yer verilmiştir. Her çalışmanın sonucunda, farklı uygulanan yöntemler sonucunda farklı ve benzer sonuçlar elde edilmiştir.

Bu çalışmalardan ilki, Eyüboğlu S. ve Eyüboğlu K. (2018), 03/01/2011 ile 26/05/2016 dönemini kapsayan çalışmalarında, Borsa İstanbul endeksleri ile döviz kurları arasındaki ilişkiyi incelemişler ve 23 sektöre ait pay senedi endeksleri ve BIST 100 Endeksi ile Euro/TL ve Dolar/TL kurlarına ait günlük verileri kullanılarak analizlerini gerçekleştirmişlerdir. Elde edilen bulgular sonucunda çalışmalarında bulunan sektör endekslerinden uzun dönemde her iki döviz kuruyla bir ilişkiye sahip olan BİST Tekstil Deri endeksi olmuştur. Uzun dönemde sadece BİST Teknoloji ve Ticaret endeksleri ile Dolar/TL kuru arasında bir ilişki var oldugu so- 
nucuna varmışlardır. Bununla birlikte kısa dönemde ise, 3 endeks ile döviz kurları arasında negatif, uzun dönemde ise pozitif bir ilişki olduğu belirlemişlerdir.

Benli (2015)'de yaptığ 1 çalışmasında, BİST 100 ve sektör endeksileri ile dolar kuru arasındaki uzun ve kısa dönemli ilişkilerini incelemiştir. Çalışması sonucunda uzun dönemde , BİST 100 endeksi ve sektör endeksleri ile dolar şatış kuru arasında herhangi bir ilişkiye rastlamamıştır. Uzun dönemde bir ilişkiye olmamasının yanında kısa dönemde ise, BİST 100 endeksi, teknoloji ve hizmet sektör endeksleri ile dolar kuru arasında çift yönlü bir nedensellik ilişkisine sahip olduğu, dolar kuru ile tek yönlü ilişkiye sahip olan endeksi ise mali sektör endeksi olduğu bulgularına varmıştır. Bununla birlikte kısa dönemde dolar kuru ile herhangi bir ilişkiye rastlanmayan endeks sanayi sektör endeksi olduğu tespit etmiştir.

Doğukanl, Özmen ve Yücel (2010), Ocak 1999-Haziran 2009 dönemini kapsayan çalışmalarında veri olarak hizmet, sinai ve mali ana sektör ve 15 alt sektör pay senedi endeksleri ele almışlardır. Çalışmaları sonucunda elde edilen bulgulara göre, döviz kurları ile sektörler arasında uzun dönemde bir ilişki olduğu sonucuna varmışlardır. Her bir sektörün döviz kurunua olan duyarlılıgı farklılık gösterdiği, bunlardan mali sektör Euro kuru açısından negatif forex betaya sahip iken dolar kuru açısından bakıldığında pozitif forex betaya sahip bulunmuştur. Bunun yanında dolar kuru açısından sınai sektörleri pozitif forex betaya sahip olduğunu gösterirken, hizmetler sektörünün negatif forex betaya sahip olduğunu gösterdiği sonucu elde etmişlerdir. Euro kuru açısından, sınai sektörünün pozitif forex betaya, hizmetler sektörlerinin negatif forex betaya sahip oldukları sonucuna varmışlardır. Her iki döviz kuruna göre incelendiğinde, en yüksek duyarlılık gösteren sektör hizmetler sektörü olurken, en düşük duyarlılıga sahip sektör ise mali sektör olmuştur. Her iki para birimi ile sektörler arasındaki kısa dönemli ilişkileri hata düzeltme modeli aracılığıyla incelemeleri sonucunda uyarlama hızı en düşük ulaştırma sektörü en yüksek sektör ise gıda sektörü olduğu tespit etmişlerdir.

Boyacıoğlu ve Çürük (2016), çalışmalarında döviz kurunda oluşan bir değişimin hisse senedi getirisi üzerindeki etkisini ortaya koymayı amaçlamışlardır. Çalışmaları sonucunda, reel döviz kuru endeksinde 
oluşan bir değişim sonucunda hisse senedi getirisi üzerinde pozitif anlamlı bir etkisinin olduğu sonucuna varmışlardır.

Kendirli ve Çankaya (2016), 2009:1-2015:3 dönemini kapsayan çalışmalarında değişkenler olarak, BİST Bankacıllk Endeksi, TÜFE ve Amerikan doları ile ilgili verileri ele alarak enflasyon ve dolar kurunda oluşan bir değişimin BİST Bankacılık Endeksi üzerindeki etkisini ortaya çıkarmak amaçlamışlardır. Çalışmaları sonucunda elde ettikleri bulgulara göre analizi yapılan dönemde enflasyonun ve döviz kurlarının \%5 anlamlılık seviyesinde BİST Bankacılık Endeksi üzerinde anlamlı bir etkisi olmadığ 1 sonucuna ulaşmışlardır. Buna karşılık sonuçları \%10 kritik değer seviyesinde incelendiğinde BİST Bankacllık Endeksinden dolar kuruna doğru tek yönlü bir ilişki var olduğunu tespit etmişlerdir.

International Conference on Eurasian Economies (2014), çalışmada ele alınan değişkenler olarak BİST 30 endeskis ile dolar kurunu almıştır ve değişkenler arasındaki nedensellik ilişkisini kapanış değerleri ile günlük ve aylık veriler olarak ayrı ayrı değerlendirilmiştir. Dolar kuru bagımsız değişkne BİST 30 endesksi bagımlı değişkne ılarak belirlenmiş ve aylık verileri gore elede edilen bulgular sonucunda BİST 30 endeksi ile dolar kuru arasında herhangi bir nedensellik ilişkisi görülmemiştir. Ancak aynı dönemin günlük verileri sonuclarına gore incelendiginde BİST 30 endeksi ile dolar kuru arasında tek yönlü bir nedensellik ilişkisi olduguna ve ayrıca dolar kurunda oluşan bir değişim BIST 30 endeksindeki değişimlerin nedenidir sonucu bulgularına ulaşılmıştır.

Coşkun ve Ümit (2016), 2000:01-2014:07 döneminin aylık verilerini kapsayan çalışmalarında, altın fiyatı, BİST 100 endeksi getirisi, mevduat faiz oranı, reel konut fiyat endeksleri, döviz kuru değişlerini ele almışlardır. Çalışmalarında yapısal kırılmaları dikkate alan ve almayan yöntem sonuçlarını karşılaştırmışlardır. Buna gore Johansen eşbütünleşme yöntemi sonucunda uzun dönemde seriler arasında bir tane eş bütünleşmeilşkine rastlanmışken, diğer bir yöntem olan maki testi analizi sonucunda uzun dönemde seriler arasında bir ilişki olmadığı sonucuna varmışlardır.

Uzun ve Güngör (2017)'de yapmış oldukları çalışmalarında bazı makroekonomik göstergeler ile borsa endeksi arasındaki ilişkiyi ortaya koymaya çalışmışlardır. Elde edilen bulgulara gore hem gelişmekte hem 
hem gelişmiş ülke borsalarında ve makroekonomik değişkenlerinin bazıları aralarında çift yönlü nedensellik ilişkisi olduğu sonucuna varılmıştır. Bunun yanı sıra az gelişmiş ülkelerde çift yönlü nedensellik ilişkisine rastlanılan seriler borsa ve faiz oranı arasında iken, tek yönlü nedensellik ilişkisine sahip olan değişkenler ise borsa ile sanayi üretim endeksi ve para arzı arasında var olduğu sonucuna varmışlardır.

Özcan (2015), 1995-2011 dönemini kapsayan çalışmasında en çok Türkiye'ye gelen turist sayısını gösteren ilk 20 ülkeyi ele almış ve küresel boyutta turizm gelirlerinde önemli rol oynayan değişkenlerden turistik hizmet ve ürünün fiyatları, kişi başına düşen GSYİH ve döviz kuru gibi makroekonomik götergelerini ele alarak panel veri analizi yöntemi ile çalişmasını gerçekleştirmiştir. Çalışması sonucunda elde etmiş olduğu sonuç, turizm gelirleri üzerinde etkili olan değişkenler olarak reel döviz kuru ve kişi başına düşen GSYİH olmuştur. Ayrıca analizde kullanılan diğer değişkenlerin tümüde truzim gelirleri üzerinde önemli bir etkiye sahip olduğu sonucuna varmıştır.

Büberkökü (2013)'de yapmış olduğu çalışmasında bazı gelişmekte olan ve gelişmiş olan ülkelerin pay senetleri fiyatları ve döviz kurları arasında bir ilişkiye sahip olup olmadığını incelemiştir. Gelişmiş ülkeler grubunda, Almanya, Avustrulya, Japonya, Ingiltere, Kanada ve Isviçre; gelişmekte olan ülkeler grubunda ise, G. Kore, Singapur ve Türkiye gibi ülkeleri ele alarak çalışmasını gerçekleştirmiştir. Çalışma sonucunda pay senetleri fiyatından döviz kurularına doğru tek yönlü bir ilişkiye sahip olan ülke Kanada ve Işviçre ülkeleri olmuşken; herhangi bir nedensellik ilişkisine rastlanılmayan ülkeler olarak Japonya, Almanya, İngiltere ve Avusturalya olmuştur. Singapur ve G. Kore ülkelerinde tek yönlü bir nedensellik ilişkisine rastalnılmış ve bu ilişkinin yönünü ise döviz kurundan pay senedi fiyatlarına doğrudur. Türkiye bunun tersi olarak hisse senedi fiyatlarından döviz kurlarına doğru bir nedensellik ilişkisine rastlamıştır. Değişkenler arasında sadece uzun dönemli bir ilişkye sahip olan ülke Singapur olmuştur.

Aydın (2017), çalışmasında dönemin gelişmekte olan ülkeler grubunda olan Meksika, Çin, Filipinler, Brezilya, Endonezya, Türkiye ve Arjantin gibi ülkeler için döviz kuru ile pay senedi fiyatı arasında ne tür bir ilişkiye sahip olduğunu incelemiştir. Çalışmada elde edilen bulgular sonucunda değişkenler arasındaki nedensellik ilişkilerinin ele alınan 
ülkeler için farklılaştığ görülmüş, aynı zamanda simetrik testlerin ortaya çıkaramadığı gizli ilişkilerin asimetrik testler yardımıyla ortaya çıkarıldığını tespit etmiştir.

Başarır ve Keten (2016), çalışmalarında JP Morgan EMBI endeksi içerisinde yer alan 12 adet gelişmekte olan ülkenin pay senedi endeksleri ve CDS primleri ile döviz kurları arasında uzun ve kısa dönemde bir ilişkiye sahip olup olmadıklarını ortaya çıkarmayı amaçlamışlardır. Çalışma sonucunda elde edilen bulgulara göre, çalışmaya dahil olan ülkelerin CDS primleri ile pay senetleri arasında $\% 95$ anlamlılık düzeyinde çift yönlü bir nedensellik ilişkisine rastlanılmış bunun yanında döviz kuru ile uzun ve kısa dönemde herhangi bir nedensellik ilişkisine rastlanılmadığı sonucuna varmışlardır.

Güvercin (2016), 01.01.2002 ve 31.12.2015 dönemlerini kapsayan çalışmasında "kırılgan beşli" olarak nitelendirilen ülkelerin (Endonezya, Hindistan, Türkiye, Brezilya ve Güney Afrika) pay senedi fiyaltarı üzerinde $\mathrm{ABD}$ dolarındaki değişmelerin ne gibi bir etkiye sahip olduğunu regresyon modeli yöntemi ile incelemiştir. Çalışma sonucunda elde edilen bulgular göre, $\mathrm{ABD}$ dolarının değişmesinin hisse senedi piyasa endeksleri üzerindeki birebir etkisine bakılmış, bunun sonucunda küresel finansal kriz öncesi dönemde 5 ülkenin pay senedi fiyatındaki değişimin ABD doları değişiminden kaynaklandığı sonucuna varılmıştır. Bunun yanında küresel finansal kriz sonrası dönem sonucuna göre ise, bu sayı bir ülkeye düşmüş ve sadece 1 ülkenin pay senedi piyasa endeksi üzerinde etkili olduğu sonucuna varmıştır.

İşcan (2011), türkiye için hisse senedi fiyatı ile amerikan doları ve euro kurları arasındaki etkileşimi, Aralık 2001 ve Aralık 2009 dönemine ait verilerle ele almış ve her iki yabancı para birimi için elde edilen bulgular karşılaştırmıştır. Çalışma sonuçlarına göre uzun dönemde bu iki finansal değişken arasında bir ilişki bulunmadığı sonucuna varmıştır. Uzun dönemli ilişkinin bulunmamakla birlikte, kısa dönemde İMKB100 endeksinde bir değişme her iki döviz kurununda nedeni olduğu sonucuna varmıştır. Bu nedenselliğin yönü ise İMKB100 endeksinden döviz kuruna doğrudur.

Özçiçek (2010), Türkiye' de hisse senedi endeks getirileri ve döviz kuru getirisi oynaklıkları arası asimetrik ve simetrik ilişkisini incelemiştir. Çalışması sonucu elde ettiği bulgularından biri borsadaki oyankları ve 
kur arasındaki ilişkinin aynı ay içerisinde güçlü oldugu sonucunu tespit etmiştir. Ancak net portföy yatırımları borsa ve kurdaki oluşan oynaklık durumundan etkilenmediği sonucuna varmıştır. Bununla birlikte kurun ve borsa endekslerinin fiyatlarının artması ve azalmasındaki etkisi aynı olmadığı ve borsa endeksleri düşerken veya kur yükselirken (olumsuz hal) etkinin daha güçlü olduğu sonucuna ulaşmıştır.

Özmen (2007), 1989-2006 yılları arası günlük verileri ele alarak, farklı döviz kurları rejimleri altında, Türkiye için pay senedi fiyatları ile döviz kurları arasındaki ilişkinin varlığını analiz etmiştir. Çalışma sonucunda 2000 yılı verileri çalışma dışında bırakıldığı durumda alt dönem sonuçları haricinde uzun dönemde, değişkenler arasında bir ilişkisinin varlığı ortaya çıkarmıştır. 1989-1994 ve 1994-1999 dönem verileri çalışma dışında bırakıldığında, değişkenler arasında çift yönlü bir nedenselliğin olduğu sonucuna varmıştır. Kriz öncesi ve 2000 yılı çalışma dişında bırakıldığında ise, değişkenler arasında tek yönlü bir nedensellik ilişkisi olduğu sonucuna varmıştır.

Ceylan ve Şahin (2015)'de yapmış oldukları çalışmalarında, döviz kuru ve hisse senedi fiyatları arasındaki ilişkiyi araştırmışlardır. 2006:1-2015:4 dönemi aylık verilerinin kullandıkları çalışma sonucu elde edilen bulgulara göre, döviz kuru ve pay senedi fiyatları aynı seviyede durağan ve koentegre oldukları, döviz kurundan pay senetleri fiyatlarına doğru güçlü bir nedensellik ilişkinin var olduğu ve diğer taraftan pay senetlerinden döviz kurlarına doğru nedensellik ilişkinin olmadığı sonucuna varmışlardır.

\section{Metodoloji}

\section{Örneklem ve Veri Toplama}

02/01/2015 ile 30/03/2018 tarihleri arasında oluşan BİST Turizm endeksi ile döviz kurlarının günlük verileri ele alınmıştır. Günlük verilerin kullanılmasındaki amaç, BIST Turizm endeksi ile Ameriken doları ve Euro kurunda oluşan fiyat değişimlerini daha iyi görebilmek ve yapılacak olan analiz sonuçlarını daha iyi elde edilebilmesi açısından ele alınmıştır. Eğer frekansı daha düşük olan verilerin kullanıldığı aşamada nedensellik testleri sonucu yapay istatistikî anlamlılığa sebep olabilmektedir 
(İşcan, 2011:245). BIST Turizm Endeksinde günlük kapanış fiyatları kullanılmış ve Finnet web sitesi verilerinden elde edilmiştir. Diğer bir değişken olan döviz kuru olarak Amerikan dolar ile Euro para birimi günlük kapanış satış fiyatları ele alınmış olup Türkiye Cumhuriyeti Merkez Bankası Elektronik Veri Dağıtım Sisteminden (EVDS) elde edilmiştir. Toplam gözlem sayısı 821'dir. Analizlerin gerçekleştirilebilmesi için E-Views 10 paket programından yararlanılmıştır.

\section{Yöntem}

Bu çalışmada zaman serileri yöntemlerini ele alınarak üç değişken kullanılarak analiz gerçekleştirilmiştir. Bu değişkenler BİST Turizm endeksi, Amerikan doları ve Euro kurudur. İlk olarak çalışmada yer alan tüm verilerin logaritmaları alınmıştır. Logaritmalarının alınmasındaki amaç serilerin hepsinin aynı düzeyde yer almasını sağlamaktır. Verilerin durağan olup olmadıklarına bakılmak amacıyla Dickey ve Fuller (1981) tarafından geliştirilen "Geliştirilmiş Dickey-Fuller" (ADF) birim kök testi uygulanmıştır. Daha sonra Johansen eşbütünleşme yöntemini uygulayabilmek için değişkenlerin ilk düzeyde durağan olmadıkları için birinci farkı alınarak durağanlık sağlanmış ve optimal gecikme uzunluğu belirlenmiştir. Belirlenen gecikme uzunluğu değeri ile değişkenlerin uzun dönemli ilişkilerini görmek amaciyla Johansen Eşbütünleşme testinden yararlanılmıştır. Bunun yanında kısa dönemli ilişkilerini araştırmaya yönelik Granger Nedensellik testi uygulanmıştır. Diğer bir zaman serisi yöntem olarak çalışmada ele alınan değişkenlerin ekonomik bir olay karşısında serilerin değişimini görmek amacıyla VAR Etki-Tepki fonksiyonu uygulanmış olup buna ilaveten her bir rassal ekonomik şokun, gelecek zamanlar için elde edilen öngörünün hata varyansına olan etkisini ortaya koymak için Varyans ayrıştırması yöntemi kullanılmıştır.

\section{Bulgular}

Çalışmada ekonometrik analize geçmeden önce 02/01/2015 ile 30/03/2018 tarihleri arasında oluşan verilerin genel yapısını görmek amacıyla tanımlayıcı istatistiki değerleri logaritmik (Ln) değerleriyle Tablo 1'de yer verilmiştir. 
Tablo .1. Değişkenlerin Tanımlayıcı İstatistikleri

\begin{tabular}{llll}
\hline & LNTURIZM & LNDOLAR & LNEURO \\
\hline Ortalama & 8.813957 & 1.149673 & 1.265788 \\
\hline Medyan & 8.736592 & 1.105025 & 1.212387 \\
\hline Maxsimum & 9.193849 & 1.386819 & 1.601184 \\
\hline Minimum & 8.405748 & 0.825008 & 0.966261 \\
\hline Std. Sapma & 0.190822 & 0.141718 & 0.158512 \\
\hline Çarpıklık & 0.395998 & -0.088589 & 0.288872 \\
\hline Basıklık & 1.764859 & 1.892003 & 2.014947 \\
\hline Jarque-Bera & 73.64476 & 43.06999 & 44.61168 \\
\hline Olasılık & 0.000000 & 0.000000 & 0.000000 \\
\hline Toplam & 7236.259 & 943.8816 & 1039.212 \\
\hline Toplam Sq. Dev. & 29.85870 & 16.46880 & 20.60327 \\
\hline Gözlem Sayıs1 & 821 & 821 & 821 \\
\hline
\end{tabular}

Tablo 1'e göre toplam 821 gözlem sayısından oluşan serilerden en fazla oynaklığa yani standart sapmaya sahip olan (0.190822) değişken BİST Turizm endeksi olmuştur. Buna karşılık en düşük oynaklığa yani standart sapmaya (0.141718) sahip olan değişken ise dolar kuru olmuştur.

\section{Birim Kök Testi}

Makro iktisadi zaman serileri genel biçimde değerlendirildiğinde birim köke sahip oldukları yanı durugan olmayan seriler olduğu veya varyansları ileriki dönemlerde artttı̆g 1 bilinmektedir. Zaman serilerinde oluşan bu ilişki en küçük kareler tahmin edicisi yöntemi ile sahte regresyon tahminlerini ortaya çıkarabilmektedir. Bu sebepten dolayı ele alınan verileri bu ampirik çalışmaya başlamadan önce serilerin hepsinin aynı derecede entegre olmasını saglamak amacıyla birim kök testi olarak bilinen durağanlık testine tabi tutmamız gerekmektedir (İşcan, 2011, s.245). Literatürde serilerin durağanlığını sağlamak için birçok yöntem bulunmaktadır. Bu çalışmada literatürde genellikle kullanılan Geliştirilmiş Dickey-Fuller (ADF) birim kök testi uygulanmıştır. ADF birim kök testi için kurulan hipotezler şöyledir. 
- Ho: Birim kök vardır (Seriler durağan değildir).

- Ha: Birim kök yoktur (Seriler durağandır).

Birim kök testi uyğulaması sonucunda elde edilen ADF test istatistiklerinin, kritik değer ile karşılaştırılması sonucunda, Ho hipotezinin kabul edilmesine yada reddedilmesine karar verilir. Ho hipotezi birim köke sahip olduğunu yani serinin tümünün aynı seviyede olmadığı, duragan olmadığına diğer alternatif hipotez ise (Ha) serinin birim kök içermediğini yani serilerin tümünün aynı seviye olduğu, durağan olduğunu göstermektedir. Analiz sonucunda eğer hesaplanan, düzey değerde sabitsiz/trendsiz ADF test istatistikleri, kritik değerlerden mutlak olarak büyükse Ho hipotezi reddine yani serinin durağan olduğuna ve birim köke sahip olmadığına karar verilir (Benli, 2015, s.62).

Tablo 2. Değişken Serilerine Ait ADF Birim Kök Test Sonuçları

\begin{tabular}{llll}
\hline DEĞİŞKEN & DÜZEY & & BİRINCI FARK \\
\hline LnDolar & Sabit & Sabit ve Trend & Sabitsiz ve Trendsiz \\
\hline LnEuro & -1.340976 & -2.417745 & -26.42027 \\
\hline LnXTRZM & 0.194862 & -2.421654 & -26.56196 \\
\hline
\end{tabular}

Tablo 2'ye göre serilerin ilk düzeyde durağan olmadıkları yani birim kök içerdiği görülmüştür. Ardından serilerin birinci farkı alındığında durağan hale gelmiştir.

\section{Johansen Eşbütünleşme Analizi}

Johansen Eşbütünleşme testi, ele alınan değişkenlerin uzun dönemde birlikte harekete edip etmediklerini ortaya koyan bir analiz yöntemidir.

Eşbütünleşme testini uygulayabilmemizin imkanı tüm değişkenlerin birinci dereceden entegre olması ile sağlanmaktadır (İşcan, 2011, s.246).

Bu doğrultuda bu çalışmada Johansen eşbütünleşme yöntemini uygulayabilmek için önce logaritmaları alınmış verilerle VAR modeli kullanılarak optimal gecikme uzunluğu belirlenecektir. Literatürden en yaygın kullanılan gecikme uzunluğu olan LR, (AIC) Akaike Bilgi Kriteri, (FPE) Son Öngörü Hatası, (SC) Schwarz Bilgi Kriteri (HQ) Hannan-Quinn Bilgi Kriterleri dikkate alınarak belirlenmiştir. Bu kriterlerden minimum 
değerde olan gecikme uzunluğu olarak (1) optimal değer olarak kabul edilmiştir. Gecikme uzunluğu belirdikten sonra Johansen eşbütünleşme testi uygulamasına geçilmiştir.

Johansen eşbütünleşme testinde kabul edilen hipotezler şu şekildedir;

- Ho: Değişkenler arasında eşbütünleşme ilişkisi yoktur.

- Ha: Değişkenler arasında eşbütünleşme ilişkisi vardır.

Johansen eşbütünleşme testi sonucunda, İz ve Maksimum Özdeğer istatistiklerinin olasılık değeri eğer kritik değer 0.05 'den küçük ise Ho red edilir, yani değişkenler arasında uzun dönemde eşbütünleşme vardır veya birlikte hareket etmektedir denir. İz ve Maksimum Özdeğer istatistiklerinin olasılık değeri eğer kritik değer 0.05 'den büyük ise Ho kabul edilir, yani değişkenler arasında uzun dönemde eşbütünleşme yoktur veya uzun dönemde birlikte haraket etmemektedir denir (Benli, 2015, s.63).

Tablo 3. Optimal Gecikme Uzunlukları Testi Sonuçları

\begin{tabular}{lllllll}
\hline Lag & LogL & LR & FPE & AIC & SC & HQ \\
\hline 0 & 8108.883 & NA & $4.28 \mathrm{e}-13$ & -19.96523 & -19.94787 & -19.95856 \\
1 & 8145.228 & $72.33169^{*}$ & $4.00 \mathrm{e}-13^{*}$ & $-20.03258^{*}$ & $-19.96313^{*}$ & $-20.00592^{*}$ \\
2 & 8153.552 & 16.50412 & $4.01 \mathrm{e}-13$ & -20.03092 & -19.90938 & -19.98426 \\
3 & 8156.050 & 4.934975 & $4.08 \mathrm{e}-13$ & -20.01490 & -19.84127 & -19.94825 \\
4 & 8163.565 & 14.78843 & $4.09 \mathrm{e}-13$ & -20.01124 & -19.78553 & -19.92459 \\
5 & 8167.525 & 7.765395 & $4.14 \mathrm{e}-13$ & -19.99883 & -19.72103 & -19.89219 \\
6 & 8174.192 & 13.02167 & $4.17 \mathrm{e}-13$ & -19.99308 & -19.66319 & -19.86644 \\
7 & 8176.676 & 4.832744 & $4.23 \mathrm{e}-13$ & -19.97703 & -19.59506 & -19.83040 \\
8 & 8178.650 & 3.826351 & $4.31 \mathrm{e}-13$ & -19.95973 & -19.52566 & -19.79310 \\
\hline
\end{tabular}

*ölçüt tarafından seçilen gecikme uzunluğu sırasını gösterir.

LR: LR Test İstatistiği FPE: Son Öngörü Hatast

AIC: Akaike Bilgi Kriteri SC: Schwarz Bilgi Kriteri

HQ: Hannan-Quinn Bilgi Kriteri

Çalışmada gecikme uzunluğunu belirledikten sonra Tablo 4 ve Tablo 5 de Johansen eşbütünleşme İz istatistiği ile Özdeğer testi sonuçları ortaya koyulmuştur.

Tablo 4 ve 5'de yer alan her iki sonuca göre olasılık değeri kritik değer 0.05 'den büyük olduğu için Ho kabul edilir yani BIST Turizm endeksi ile Amerikan doları ve Euro kurları arasında uzun dönemde bir eşbütünleşme olmadığı, değişkenlerin uzun dönemde birlikte hareket etmediği 
sonucuna varılmıştır. Değişkenler arasında bir eşbütünleşme olmadığ1 için hata düzeltme modeli uygulanmamıştır.

Tablo 4. Johansen Eşbütünleşme İz İstatistiği Testi Sonuçlarn

\begin{tabular}{lllll}
\hline Hipotez & Özdeğer & İz İstatistiği & $\begin{array}{l}\mathbf{0 . 0 5} \\
\text { Kritik Değer }\end{array}$ & Olasılık \\
\hline Hiçbiri & 0.019070 & 25.00431 & 29.79707 & 0.1613 \\
\hline En fazla 1 & 0.010715 & 9.235207 & 15.49471 & 0.3441 \\
\hline En fazla 2 & 0.000504 & 0.412541 & 3.841466 & 0.5207 \\
\hline
\end{tabular}

Tablo 5. Johansen Eşbütünleşme Maksimum Özdeğer Testi Sonuçları

\begin{tabular}{lllll}
\hline Hipotez & Özdeğer & $\begin{array}{l}\text { Maksimum } \\
\text { Özdeğer } \\
\text { İstatistiği }\end{array}$ & $\begin{array}{l}\mathbf{0 . 0 5} \\
\text { Kritik Değer }\end{array}$ & Olasılık \\
\hline Hiçbiri & 0.019070 & 15.76910 & 21.13162 & 0.2386 \\
\hline En fazla 1 & 0.010715 & 8.822666 & 14.26460 & 0.3012 \\
\hline En fazla 2 & 0.000504 & 0.412541 & 3.841466 & 0.5207 \\
\hline
\end{tabular}

\section{Granger Nedensellik Testi}

Granger (1969) nedensellik testi, değişkenleri kısa dönemde bir ilişkiye sahip olup olmadıklarını gösteren, eğer bir nedensellik ilişkiye sahip iseler bu nedensellik ilişkilerinin yönünü ve hangi değişkeninin diğer değişkenin nedeni olduğunu ortaya koyan bir yöntemdir. Literatürde Granger nedensellik testi için kullanılan hipotezler şu şekildedir:

- Ho: Granger nedeni değildir

- Ha: Granger nedenidir

Granger nedensellik testi sonucunda, olasılık değeri eğer 0.05 'den küçük ise Ho reddedilir, yani Granger nedenidir denir. Olasılık değeri eğer 0.05 'den büyük ise Ho hipotezi kabul edilir, yani Granger nedeni değildir denir.

$\mathrm{Bu}$ doğrultuda değişkenler arasında uzun dönemde bir ilişki olmamakla birlikte kısa dönem de BİST Turizm endeksi ile Amerikan doları ve Euro kurlarının nedensellik ilişkisine bakılmak amacıyla VAR modeli ile belirlediğimiz gecikme uzunluğunu (1) kullanarak VAR temelli Pairwise Granger Causality (Granger Nedensellik) testi uygulanmıştır. 
Tablo 6'ya göre Euro kurunda meydana gelen bir değişimin \%5 anlamlılık seviyesinde BİST Turizm endeksinde meydana gelen değişimlerin üzerinde etkilidir. Yani Euro kuru BİST Turizm endeksinin Granger nedenidir. Buna karşllılık dolar kurunda oluşan bir değişimin \%5 anlamlılık seviyesinde BIST Turizm Endeksi üzerinde bir değişime neden olmamaktadır. Dolayısıyla dolar kuru BİST Turizm endeksinin Granger nedeni değildir. Ancak sonuçlar \%10 anlamlılık seviyesinde değerlendirildiğinde Amerikan dolar kurunda oluşan bir değişim BİST Turizm endeksinin Granger nedeni olmaktadır.

Tablo 6. Granger Nedensellik Testi (Pairwise Granger Causality Tests) Sonuçlarn

\begin{tabular}{llll}
\hline Boş hipotez & $\begin{array}{l}\text { Gözlem } \\
\text { sayısı }\end{array}$ & $\begin{array}{c}\text { F } \\
\text { istatistiği }\end{array}$ & Olasıllk değeri \\
\hline DEURO, DTURIZM'in nedeni değildir. & 819 & 10.0073 & 0.0016 \\
DTURIZM, DEURO'nun nedeni değildir. & & 34.9367 & $5 . E-09$ \\
\hline DDOLAR, DTURIZM'in nedeni değildir. & 819 & 3.26107 & 0.0713 \\
DTURIZM, DDOLAR'ın nedeni değildir. & & 53.6372 & $6 . E-13$ \\
\hline DEURO, DDOLAR'ın nedeni değildir. & 819 & 0.43818 & 0.5082 \\
DDOLAR, DEURO'nun nedeni değildir & & 0.58038 & 0.4464 \\
\hline
\end{tabular}

\section{Etki-Tepki Fonksiyonu Testi}

Etki-Tepki fonksiyonu testi, çalışmada yer alan değişkenlerde meydana gelen herhangi bir ekonomik olay karşısında diğer bir değişkenin serilerindeki değişimi ölçmek amacıyla uygulanan bir yöntemdir.

BİST Turizm endeksinde oluşan bir artış karşısında Amerikan dolarının ve Euro kurunun vermiş olduğu negatif ve pozitif tepkilerini şekil 1'de gösterilmiştir.

Şekil 1'e gore, BİST Turizm endeksindeki bir artış her iki döviz kurunu da etkilemektedir. BİST Turizm Endeksinde oluşan bir artış karşısında Euro kurunda oluşan değişim, ilk 4 . ayın başına kadar negatif yönde olmuş dolayısıyla buda portföy yaklaşımını desteklemektedir. Benzer biçimde BİST Turizm endeksinde oluşan bir artış karşısında Amerikan doları, 4. ayın başına kadar negatif bir tepki göstermiş ve bu doğrultuda portföy yaklaşımı desteklemektedir. Her iki döviz kuru içinde 4.ayın başından itibaren pozitif bir tepki vererek dengeye gelmişlerdir. 
Response to Cholesky One S.D. (d.f. adjusted) Innovations \pm 2 S.E.
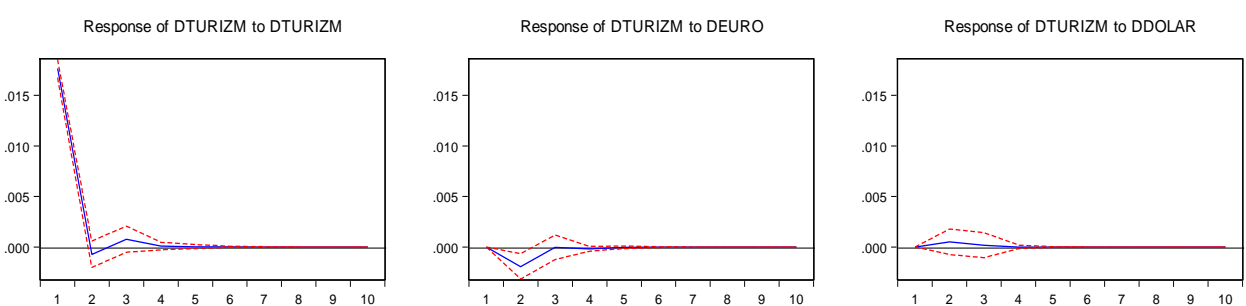

Response of DEURO to DTURIZM

Response of DEURO to DEURO

Response of DEURO to DDOLAR
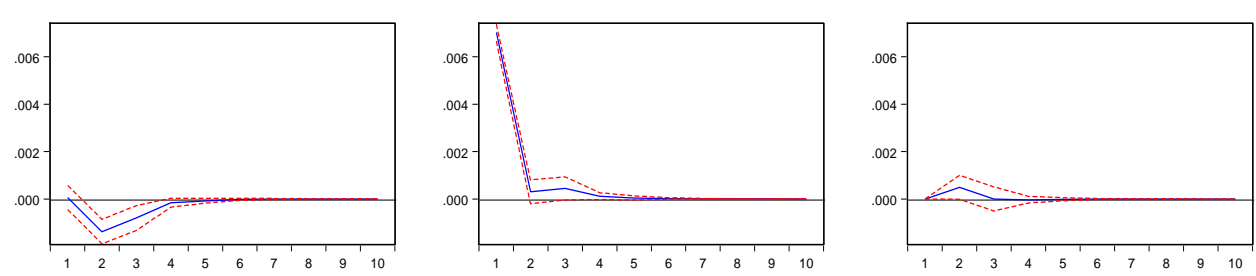

Response of DDOLAR to DTURIZM

Response of DDOLAR to DEURO

Response of DDOLAR to DDOLAR
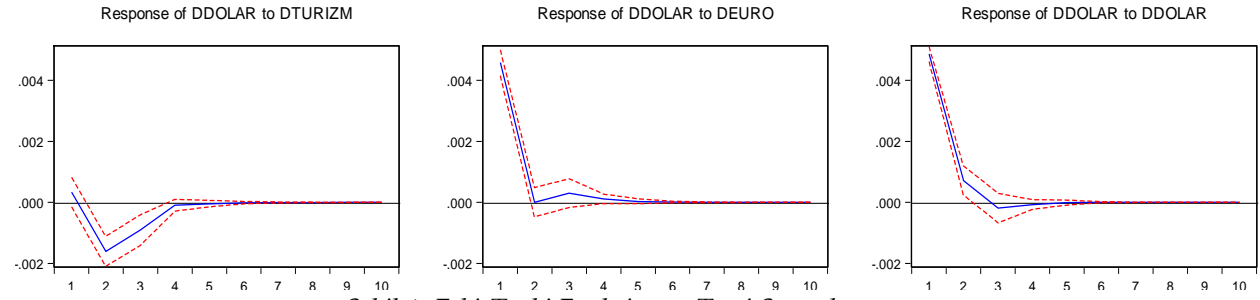

Şekil.1. Etki-Tepki Fonksiyonu Testi Sonuçları

\section{Varyans Ayrıştırması Testi}

Varyans ayrıştırması testi, çalışmada ele alınacak olan bir değişkende meydana gelen bir değişmenin hata varyansının yüzde kaçlık kısmı kendinden kalan kısmı diğer değişkenler tarafından açıklanıyor olduğunu bilgisini veren bir yöntemdir. Aşağıda yer alan Tablo 7 Varyans ayrıştırması testi sonucu BİST Turizmdeki bir değişimin hata varyansının yüzde kaçlık kısmını kendisinden, kalan kısmının Amerikan doları ve Euro kurundan kaynaklandığını göstermektedir.

Tablo 7' de elde edilen sonuçlara göre, 10 dönemlik varyans ayrıştırması sonuçları sunulmuştur. Buna göre BİST Turizm Endeksindeki değişimlerin hata varyansının birinci ayda \%100 kısmı kendisinden kaynaklanmaktadır. İkinci aydan sonra hata varyansının kendisinden 
kaynaklanma yüzdesi en son alınan dönem sayısına göre \%75.33 seviyesine kadar düşmektedir geriye kalan kısmı ise \%15.22'lik bir oranında Euro kuru ile \%9.44 oranında ise dolar kuru ile açıklanmaktadır.

Tablo 7. Varyans Ayrıştırması Testi Sonuçları

\begin{tabular}{lllll}
\hline $\begin{array}{l}\text { Variance } \\
\text { Decomposit on of DTURIZM: }\end{array}$ & & & & \\
\hline Period & S.E. & DTURIZM & DEURO & DDOLAR \\
\hline 1 & 0.019140 & 100.0000 & 0.000000 & 0.000000 \\
2 & 0.020217 & 93.57826 & 4.760464 & 1.661275 \\
3 & 0.022383 & 87.25190 & 7.936193 & 4.811908 \\
4 & 0.023883 & 84.61559 & 9.694399 & 5.690008 \\
5 & 0.025487 & 82.07525 & 11.14714 & 6.777604 \\
6 & 0.026908 & 80.18287 & 12.31652 & 7.500611 \\
7 & 0.028295 & 78.61504 & 13.24527 & 8.139688 \\
8 & 0.029601 & 77.33437 & 14.02174 & 8.643885 \\
9 & 0.030859 & 76.25157 & 14.67022 & 9.078210 \\
10 & 0.032065 & 75.33097 & 15.22512 & 9.443904 \\
\hline
\end{tabular}

\section{Sonuç}

Bu çalışmada hizmet sektöründe önemli yere sahip olan BIST Turizm endeksi ile Amerikan doları ve Euro para birimlerinin arasındaki ilişki incelenmiştir. Çalışmada analizin başında ele alınan serilerin ilk düzeyde durağan olmadıkları tespit edilmiş ve bunun sonucunda serilerin birinci farkları alınarak durağan hale getirilmiştir. Ardından finansal değişkenlerin uzun dönemdeki ilişkilerini tespit etmek amacıyla Johansen eşbütünleşme testi uygulanmıştır. Bunun sonucunda BİST Turizm endeksi ile döviz kurları arasında uzun dönemde bir ilişki bulunamamıştır. Uzun dönemde bir ilişki bulunamaması durumunda Granger nedensellik testi uygulanmıştır. Uygulama sonucunda kısa dönemde Euro kurunda meydana gelen bir değişimin \%5 anlamlılık seviyesinde BİST Turizm endeksinde meydana gelen değişimlerin üzerinde etkili olduğu yani Euro kuru BİST Turizm endeksinin Granger nedenidir sonucuna ulaşılmıştır. Bununla birlikte diğer döviz kuru olan Amerikan dolarında oluşan bir değişimin \%5 anlamlılık seviyesinde BIST Turizm Endeksi üzerinde bir değişime neden olmamaktadır. Dolayısıyla dolar kuru BİST Turizm endeksinin Granger nedeni değildir. Ancak \%10'luk anlamlılık seviyesinde 
Amerikan dolarında meydana gelen bir değişim BİST Turizm endeksinin Granger nedeni olmaktadir.

Etki tepki analizi sonucunda elde edilen bulgulara göre, BIST Turizm endeksindeki bir artış her iki döviz kurunu da etkilemektedir. BIST Turizm Endeksinde oluşan değişim karşısında Euro kurunun vermiş olduğu cevap ilk 4.ayın başına kadar negatiftir. Dolayısıyla Euro kurunun dört aylık negatif bir tepki göstermesi portföy yaklaşımını desteklemektedir. Benzer biçimde BİST Turizm endeksinde oluşan bir değişimde Amerikan doları 4. ayın başına kadar negatif bir tepki göstermiştir. Dolayısıyla Amerikan dolarının dört ay boyunca göstermiş olduğu negatif tepki portföy yaklaşımını desteklemektedir. 4.ayın başından itibaren her iki döviz kuru negatif bölgeden uzaklaşıp pozitif bir tepki vererek dengeye gelmişlerdir.

Diğer bir analiz yöntemi olan Varyans Ayrıştırması testi sonucunda BIST Turizm Endeksindeki değişimlerin hata varyansının on aylık dönemde birinci ayda \%100 kendisinden kaynaklanmaktadır. Son aylara doğru ilerledikçe BİST Turizm endeksindeki değişimlerin kendinden kaynaklanan hata varyansları gittikçe düşmüştür. En son 10. ayda BİST Turizm endeksinin kendisinden kaynaklanan hata varyans1 \%75.33 seviyesine kadar düşmüştür. Bu yüzdelik kısmının geriye kalanı kısmını \%15.22'lik oranında Euro kuru, \%9.44'lük oranında ise Amerikan dolarından kaynaklandığı sonucuna ulaşılmıştır. Çıkan sonuçlar gösteriyor ki BİST Truzim endeksinin fiyat dalgalanmalarında hata varyansının en fazla payını Euro kuru oluşturmaktadır.

En genel biçimde çalışmadan elde edilen sonuçlar dahilinde, BIST Turizm endeksinin daha çok kısa dönemde Euro kuruyla ilişkili olması ve BİST Turizm endeksindeki oluşan bir değişimin hata varyansının en fazla Euro kurundan kaynaklanması, Avrupa Birliği ülkelerinden daha çok turist ülkeye giriş sağlaması veya yapılan yatırımlarda Euro para birimin kullanması sonucunda olabileceği tahmin edilmektedir. Çalışmada ortaya çıkan sonuçlar ekonomiye önemli katkılar bulunması açısından önemli sektörlerden biri olan turizm sektörü için döviz kurundaki etkileşimindeki sonuçları ortaya koyarak gelecekte yapılacak olan yatırımlara bir katkı sağlanması açısında önemlidir. 


\title{
EXTENDED ABSTRACT
}

\section{Analysis of The Relationship Between Exchange Rate and Bist Tuorism Index}

\author{
Emine Soyaslan
}

Osmaniye Korkut Ata Üniversitesi

Advances in science and technology from the past to the present, and the globalized trade and trade in the field of commerce, as well as the good relations between the developing world states have led the country's citizens to travel to many countries and make foreign investments.

However, especially the dimension of the financial liberalization process and international capital movements has increased the importance of the relationship between stock and foreign exchange market (Büberkökü, 2013, p.2).

In particular, as a country's own currency follows an unstable course during periods, it affects the economy of that country negatively. However, the economic activity of other countries that trade in that country leads to negative instability, thus causing economic instability in the most general sense. Changes in the exchange rate affect the structure of firms as well as macro economies. The risk of loss or profit arises as a result of the depreciation of the foreign currency of the national currency or the foreign currency of the national currency due to the debts or receivables of the companies engaged in the trade of services and products in the international dimension (Boyacıoğlu ve Çürük, 2016, p.144). Therefore, these companies take their share in the enterprises in the tourism sector.

The aim of this study is to investigate the relationship between BIST Tourism index and exchange rates in short and long term. The study consists of four parts. There is an introductory section explaining the relationship between the relevant exchange rate and the stock market indices, followed by the literature studies on the subject. In the third section, the methods used for the study are mentioned. In the next stage, the aim of the research, data set and sample were explained and the findings of the 
research were started. In the fourth part of the findings, whether the series are stationary at the first level is examined by using the Granger causality test for the short-term relationships of variables and the Johansen cointegration method for the long-term relationships. In order to find out how the variables react to any economic event, VAR Effect-Response function was applied and finally tested with variance decomposition method which is another time series method. Then, the findings were analyzed and the results were formed.

The data obtained were analyzed with Ewievs 10 package program. In total, 819 data were studied within the scope of the period covered. According to the findings obtained from the analyzes conducted in the study, it is observed that there is no cointegration relationship between BIST Tourism index and exchange rates in the long run, ie variables do not move together in the long run. In addition to the absence of a long-run relationship, a short-term change in the Euro exchange rate was found to have an impact on the BIST Tourism index at $5 \%$ significance level. However, a change in the US dollar was found not to have an impact on the BIST Tourism index at a 5\% significance level, but it was concluded that a change in the US dollar had an impact on the BIST Tourism index in the short term. As a result of the study, it was concluded that the changes in the BIST Tourism index stemmed from the Euro exchange rate at $15.22 \%$ and the US dollar at $9.44 \%$ as a result of the ten-year variance decomposition test.

The results of this study are important for the tourism sector, which is one of the important sectors in terms of making significant contributions to the economy, by revealing the results of the exchange rate interaction and contributing to future investments.

\section{Kaynakça / References}

Aydın, M. (2017). Gelişmekte olan ülkelerde borsa ile döviz kurları arasındaki ilişki: Simetrik ve asimetrik nedensellik analizi. İstanbul Üniversitesi İktisat Fakültesi Ekonometri Ve İstatistik Dergisi, 27, 1-15

Başarır, Ç. ve Keten, M. (2016). Gelişmekte olan ülkelerin cds primleri ile hisse senetleri ve döviz kurları arasındaki kointegrasyon ilişkisi. 
Mehmet Akif Ersoy Üniversitesi Sosyal Bilimler Enstitüsü Dergisi, 8(15), 369-380

Büberkökü, Ö. (2013). Hisse senedi fiyatları ile döviz kurları arasındaki ilişkinin incelenmesi: Gelişmiş ve gelişmekte olan ülkelerden kantlar. IMKB Dergisi, 13(52), 1-18

Boyacioglu, M. ve Çürük, D. (2006). Döviz kuru değişimlerinin hisse senedi getirisine etkisi: Borsa İstanbul 100 endeksi üzerine bir uygulama. Muhasebe ve Finansman Dergisi, Nisan, 143-156

Ceylan, S. ve Yilmaz-Şahin, B. (2015). Hisse senedi fiyatları ve döviz kuru ilişkisi'. The Journal of Academic Social Science Studies, International Journal of Social Science, 37, 399-408 http://dx.doi.org/10.9761/JASSS2963

Çoşkun, Y. ve Öznur-Ümit, A. (2016). Türkiye'de hisse senedi ile döviz, mevduat, altın, konut piyasaları arasındaki eşbütünleşme ilişkilerinin analizi. Business and Economics Research Journal, 7(1), 47-69

Doğukanli, H. Özmen, M. ve Yücel, E. (2010). İMKB'de sektörel açıdan döviz kuru duyarlılı̆̆ının incelenmesi. Çukurova Üniversitesi Sosyal Bilimler Enstitüsü Dergisi, 19(3), 63-86

Erbaykal, E. ve Okuyan, H. A. (2007). Hisse senedi getirileri ile döviz kuru ilişkisi: Gelişmekte olan ülkeler üzerine ampirik bir uygulama. BDDK Bankacilık ve Finansal Piyasalar Dergisi, 1 (1), 77- 89

Eyüboğlu, S. ve Eyüboğlu, K. (2018). Borsa İstanbul sektör endeksleri ile döviz kurları arasındaki ilişkilerin incelenmesi: ARDL modeli. Ömer Halisdemir Üniversitesi İktisadi ve İdari Bilimler Fakültesi Dergisi, 11(1), 8-28

Güvercin, A. (2016). ABD doları kur değişimlerinin "kırılgan beşli” ülkelerinin hisse senedi endeks getirilerine etkisi: Küresel finansal kriz öncesi ve sonrası dönem karşılaştırması. Bartın Üniversitesi İ.I.B.F. Dergisi, 7(13), 336-378

İşcan, E. (2011). döviz kurları ve hisse senedi piyasası arasındaki etkileşim: Türkiye örneği:Aralık 2001-Aralık 2009. Elektronik Sosyal Bilimler Dergisi, 10(35), 237-251.

Kendirli, Ş. ve Çankaya, M. (2015). Döviz kuru ve enflasyonun BIST banka endeksi üzerindeki etkisi . MANAS Sosyal Araştırmalar Dergisi, 5(3), 215-226. 
Keskin-Benli, Y. (2015). Döviz kuru ile Borsa İstanbul 100 ve sektör endeksleri arasındaki ilişkinin ampirik analizi. Uluslararası Hakemli Beşeri Ve Akademik Bilimler Dergisi, 4(12), 55-72.

Özpinar, Ö. ve Özman, H. (2017). Türkiye - ABD güven endekslerinin kavramsal çerçevesindeki farklılıklar ve kur-endeks ilişkisi. $V$. Anadolu International Conference in Economics Bildiriler Kitabı içinde (s.1-30), May 11-13, 2017, Eskişehir, Turkey.

Özmen, M. (2007). Farklı döviz kuru rejimleri altında hisse senetleri fiyatları ile döviz kurları arasındaki ilişkinin ekonometrik analizi. Ç.Ü. Sosyal Bilimler Enstitüsü Dergisi, 16(1), 519-538

Özcan, C. (2015). Türkiye'de turizm gelirinin makroekonomik belirleyicileri: Panel veri analizi. Ç.Ü. Sosyal Bilimler Enstitüsü Dergisi, 24(1), 203-220.

Özçiçek, Ö. (2010). Türkiye'de döviz kuru getirisi ve hisse senedi endeks getirileri oynaklıkları arası simetrik ve asimetrik ilişki. IMKB Dergisi, 10(37), 1-12.

Uzun, U. ve Güngör, B., (2017). Borsa endeksleri ile ülkelerin seçilmiş makroekonomik göstergeleri arasındaki ilişkinin uluslararası boyutta incelenmesi. AİBÜ Sosyal Bilimler Enstitüsü Dergisi, 17(4), $1-30$

\section{Kaynakça Bilgisi / Citation Information}

Soyaslan, E. (2019). Döviz kuru ile BIST turizm endeksi arasındaki ilişkinin analizi. OPUS-Uluslararası Toplum Araştırmaları Dergisi, 12(18. UİK Özel Say1), 772-793. DOI: 10.26466/opus.585398 